\title{
Cost-effective design of reinforced concrete with use of self-terminated carbonation model
}

\author{
Piotr Woyciechowski ${ }^{1, *}$, Joanna Sokołowska ${ }^{1}$ \\ ${ }^{1}$ Warsaw University of Technology, Department of Building Materials Engineering, \\ al. Armii Ludowej 16, Warsaw 00-637, Poland
}

\begin{abstract}
According to Eurocodes EC0 and EC2 designing of concrete structure durable in terms of carbonation is assured by selection of suitable thickness of reinforcement concrete cover. The selection is done on the basis of structure category and concrete strength class, regardless of the concrete material composition or technological type, thus selected value is an estimation, often exaggerated. The paper presents elaborated "selfterminated carbonation model" that includes abovementioned factors and enables to indicate the maximal possible depth of carbonation. The model, in contrast to parabolic models published in the literature, is a hyperbolic function of carbonation depth in time. The paper explains why such model describes the phenomenon of carbonation better than others. The paper contains an example of calculation of the cover thickness using that model.
\end{abstract}

\section{Introduction}

Durability is one of the important determinants of building material sustainability as well as sustainability of the structure. Durability of reinforced concrete structures exposed to any environment depends on the ability of both - concrete and reinforcement - to resist the environmental factors. The most common cause of the reinforced concrete damage is the corrosion of steel due to lack of providing it with efficient protection by concrete cover. The protective abilities of concrete cover deteriorate with time because of the synergistic action of a number of physical and chemical factors. One of the most destructive factors apart from local climatic phenomena (including frost or chemical aggression) is decrease in concrete $\mathrm{pH}$ value due to the activity of atmospheric carbon dioxide. Providing the durability of reinforced concrete structure working under certain environment conditions depends on providing proper (1) durability of concrete, (2) proper thickness of the concrete cover, as well as taking into consideration (while designing) serviceability limit states in terms of cracks, namely (3) calculating crack width which would not exceed the Eurocodes limits (EN 1991 Eurocode: Basis of structural design - "EC0" and EN 1992 Eurocode 2: Design of concrete structures - "EC2"). Concrete elements and structures should meet the design requirements of the expected service life without significantly reducing the serviceability or incurring excessive and unforeseen construction and maintenance costs.

* Corresponding author: p.woyciechowski@,il.pw.edu.pl 


\section{Durability in terms of standard requirements}

Principles of material design of concrete durability adopted in Europe are given in European standard EN 206: Concrete. Specification, performance, production and conformity and in national complements in relation to the local operating conditions of the structure (eg. in Polish Complement PN-B-06265:2004). From the carbonation threat point of view, principles and requirements are various for four concrete carbonation exposure classes. The criterion of assigning to the particular exposure class $\mathrm{XC} 1 \div \mathrm{XC} 4$ is concrete cover humidity and it is corresponding with environment as follows: $\mathrm{XC1}$ - dry or permanently wet environment (eg. building interiors or concrete permanently under water), XC2 - wet, rarely dry environment (eg. foundation), XC3 - medium moist environment (eg. interiors of high $\mathrm{RH}$ or exterior surfaces sheltered from the rain), XC4 - cyclically wet and dry environment (eg. zone of water flow in natural water area or fluctuations in water level in reservoirs). For each exposure class there are formulated requirements in terms of water-cement ratio, concrete class and minimal content of cement (Table 1).

Table 1. Requirements for concrete by carbonation exposure class according to EN 206.

\begin{tabular}{|c|c|c|c|c|}
\hline \multirow{2}{*}{ Requirement } & \multicolumn{4}{|c|}{ Exposure class } \\
\cline { 2 - 5 } & XC1 & XC2 & XC3 & XC4 \\
\hline Maximal value of $\mathrm{w} / \mathrm{c}$ & 0,65 & 0,60 & 0,60 & 0,50 \\
\hline Minimal concrete class & $\mathrm{C} 16 / 20$ & $\mathrm{C} 16 / 20$ & $\mathrm{C} 20 / 25$ & $\mathrm{C} 25 / 30$ \\
\hline Minimal cement content, $\mathrm{kg} / \mathrm{m}^{3}$ & 260 & 280 & 280 & 300 \\
\hline
\end{tabular}

According to standard EN 206, fulfilling abovementioned requirements ensures the durability of concrete for 50 years. Moreover, in Polish Complement there are given recommendations for the use of cements in the conditions of carbonation exposure class. For instance CEM I is suitable to use in all carbonation exposure classes. However, although all cements are recommended to use in exposure class $\mathrm{XC1}$ and $\mathrm{XC} 2$, the cements rich in limestone, fly ash, slag, etc. are not recommended to use in environments described by classes $\mathrm{XC} 3$ and $\mathrm{XC} 4$ or in case of pre-stressed concrete.

The requirements in terms of the minimal thickness of the concrete cover due to durability formulated in Eurocode EC2 are different in case of reinforced concrete structures and pre-stressed concrete structures; also they are different for each type (category) of structure defined in Eurocode EC0 and exposure class defined in the standard EN 206. Due to Eurocodes recommendations, when determining the structural class the exposure class XC specifics is to be taken into account. The structural class recommended by EC2 for "common" structures designed for service life of 50 years is S4. If the service life of the structure is 100 years, then structural class is to be increased by 2 , while in case of concrete strength class higher than $\mathrm{C} 30 / 37$ or in case of the slab elements, or in situation where the concrete special quality control is required - structural class may be reduced by 1 .

The analysis of the EC0 and EC2 indicates a certain inconsistency in records concerning the structural class. In EC0 there are defined 5 categories of structure, while in EC2 there are specified 6 classes. The record in EC2 about the need to increase the structural class S4 by 2 in case of assumption of a 100-year period of use leads to structural class S6 that refers to the 100 years of use. However, the same period of use is given in EC0 in relation to the category S5. It seems logical to assume that the record about the need to increase structural class S4 by 2 (i.e. to S6) should apply only to the case of the structure of the required service life of over 100 years (although this is not the case described in EC0).

Knowing the structural class determined according to EC0 and EC2 (Fig. 1) and specific requirements for concrete exposure class XC given in standard EN 206 (Table 1), it is 
possible to determine the minimal thickness of concrete cover $\left(\mathrm{c}_{\min , \mathrm{dur}}, \mathrm{mm}\right)$ required in case of reinforced concrete threatened by carbonation (Table 2).

\begin{tabular}{|c|c|c|c|c|c|c|c|}
\hline $\begin{array}{l}\text { Service } \\
\text { time, } \\
\text { years }\end{array}$ & Example of structure & $\begin{array}{c}\text { Structural } \\
\text { class } \\
\text { (category)* }^{\text {catego }}\end{array}$ & & \multicolumn{4}{|c|}{$\begin{array}{l}\text { Correction of structural class S4 } \\
\text { according to: }\end{array}$} \\
\hline$<10$ & Temporary structures & S1 & \multirow{2}{*}{$\begin{array}{l}\text { Exposure } \\
\text { class }\end{array}$} & Concrete & & Special & Service \\
\hline $10 \div 25$ & $\begin{array}{l}\text { Removable part of } \\
\text { structures }\end{array}$ & S2 & & class & elements & $\begin{array}{l}\text { quality } \\
\text { control }\end{array}$ & $\begin{array}{c}\text { life }>100 \\
\text { years }\end{array}$ \\
\hline $15 \div 30$ & $\begin{array}{l}\text { Agricultural structures, } \\
\text { etc. }\end{array}$ & S3 & $\mathrm{XC1}$ & $\begin{array}{l}\text { If } \geq \mathrm{C} 30 / 37 \\
\text { then } \\
\mathrm{S} 4-1=\mathrm{S} 3\end{array}$ & \multirow{3}{*}{$\begin{array}{l}\mathrm{S} 4-1 \\
=\mathrm{S} 3\end{array}$} & \multirow{3}{*}{$\begin{array}{l}\mathrm{S} 4-1= \\
\quad \mathrm{S} 3\end{array}$} & \multirow{3}{*}{$\begin{array}{l}\mathrm{S} 4+2 \\
=\mathrm{S} 6\end{array}$} \\
\hline 50 & $\begin{array}{l}\text { Buildings and other } \\
\text { common structures }\end{array}$ & S4 & $\begin{array}{l}\mathrm{XC} 2 \\
\mathrm{XC} 3\end{array}$ & $\begin{array}{l}\text { If } \geq \mathrm{C} 35 / 45 \\
\text { then } \\
\mathrm{S} 4-1=\mathrm{S} 3\end{array}$ & & & \\
\hline 100 & $\begin{array}{l}\text { Monumental build., } \\
\text { bridges and other eng. } \\
\text { structures }\end{array}$ & S5 & $\mathrm{XC} 4$ & $\begin{array}{c}\text { If } \geq \mathrm{C} 40 / 50 \\
\text { then } \\
\mathrm{S} 4-1=\mathrm{S} 3 \\
\end{array}$ & & & \\
\hline$>100$ & Special structures & S6 & & & & & \\
\hline
\end{tabular}

*) basis for determining minimal concrete cover thickness (see Table 2)

Fig. 1. Determining the structural class according to E EC0 and EC2 and specific of standard EN 206.

Table 2. Minimal concrete cover thickness required in reinforced $(\mathrm{R})$ and pre-stressed $(\mathrm{P})$ concrete threatened by carbonation.

\begin{tabular}{|c|c|c|c|c|c|c|}
\hline \multirow{2}{*}{$\begin{array}{c}\text { Structural } \\
\text { class }\end{array}$} & \multicolumn{3}{|c|}{ Minimal concrete cover thickness $\mathbf{c}_{\text {min,dur }}$ in the exposure class, mm } \\
\cline { 2 - 7 } & \multicolumn{2}{|c|}{ XC1 } & \multicolumn{2}{c|}{ XC2, XC3 } & \multicolumn{2}{c|}{ XC4 } \\
\cline { 2 - 7 } & R & P & R & P & R & P \\
\hline S1 & 10 & 15 & 10 & 20 & 15 & 25 \\
\hline S2 & 10 & 15 & 15 & 25 & 20 & 30 \\
\hline S3 & 10 & 20 & 20 & 30 & 25 & 35 \\
\hline S4 & 15 & 25 & 25 & 35 & 30 & 40 \\
\hline S5 & 20 & 30 & 30 & 40 & 35 & 45 \\
\hline S6 & 25 & 35 & 35 & 45 & 40 & 50 \\
\hline
\end{tabular}

Taking into consideration above it can be concluded that according to Eurocodes EC0 and EC2 the concrete cover thickness in the particular exposure class depends only on the structural class (category) and concrete compressive strength class - it is not differentiated for various cements and additives, nor technological types of concrete. As a consequence, the selected value of concrete cover thickness is in fact an estimation, often exaggerated (too safe or too risky).

\section{Research significance}

This paper contains authors own [1-5] mathematical model of carbonation. The model defines the carbonation as the process of limited possible range into the concrete and is described by hyperbolic function of time. The presented model of carbonation progress is different from the traditional models described by parabolic functions that were published worldwide so far (for details see paragraph 4), but it was verified in a wide range of material variables, technological variables as well as environmental variables published in 
the earlier works of the authors. Meanwhile the given algorithm enables optimal choice of the concrete cover thickness, which minimizes the uncertainty occurring during designing the reinforced concrete structures according to the simplified approach discussed in the first part of this paper.

\section{Carbonation models}

\subsection{Traditional approach to mathematical model of carbonation}

Research on the development of universal models of carbonation describing its changes in time and taking into account different material and technological variables has been conducted for many years in various research centres [6-17]. In modeling of carbonation a key issue is to determine the intensity of carbon dioxide flow through concrete. The starting point is the first Fick's law that enables to describe the diffusion process under a constant density of the diffusion flux. Final result of carbonation modeling is power function of carbonation depth in time expressed in the form:

$$
x=\sqrt{\frac{2 D \varphi_{e x t}}{a}} \cdot \sqrt{t}
$$

where: $\mathrm{x}$ - carbonation depth; $\mathrm{D}$ - diffusion coefficient; $\varphi_{\mathrm{ext}}-\mathrm{CO}_{2}$ external concentration; $\mathrm{t}$ time; a - coefficient determining the amount of $\mathrm{CO}_{2}$ bound in the way of carbonation by unit volume of concrete (in $\mathrm{kg} / \mathrm{m}^{3}$ ) calculated according to the CEB Bulletin [18]. In practice the model is simplified (it relates to an average constant $\mathrm{RH}$ and carbon dioxide concentration in the environment). The most common model used by most of the researchers (e.g. mentioned before [6-17]) as a basic model that determines the depth of carbonation, $\mathrm{x}$ after the time of exposure, $\mathrm{t}$ can be expressed in the form:

$$
x=A \cdot t^{1 / 2}+B
$$

\subsection{Model of carbonation as the finite process}

The abovementioned models consider the phenomenon of carbonation as process occurring due to exposure concrete to environment containing $\mathrm{CO}_{2}$ - unlimited in concrete space and unlimited in time. It is assumed that the end of carbonation is related only to the exhaustion of reagents available in the system, including mainly $\mathrm{Ca}(\mathrm{OH})_{2}$ and in the further horizon other hydrates. However, an important issue is the accessibility of $\mathrm{CO}_{2}$ into the system, especially, in the deeper layers of concrete. Diffusion of $\mathrm{CO}_{2}$ depends not only on the concentration gradient but also on the concrete microstructure. The abovmentioned models based on the first Fick's law assume that the medium in which diffusion takes place will not change over time, which allows the reception of a constant diffusion flux in the equation (1). This is a significant simplification of carbonation process description, which does not take into account a number of additional factors, such as changes in diffusivity as a function of humidity, changes in atmospheric concentrations of $\mathrm{CO}_{2}$ in climatic year, participation in the carbonation of $\mathrm{CSH}$ phase and residuals of non-hydrated cement, qualitative and quantitative characteristics of the material composition of concrete (w/c, type of cement, additives, admixtures, aggregates size and content), technological and environmental 
factors (curing, temperature, state of stress) and, first of all, diffusivity changes resulting from changes in time of the concrete microstructure. The latter effect, resulting from the saturation of the pores with carbonation products, limits the possibility of a direct description of a process based on Fick's law. The result of carbonation is a decrease in porosity, in particular capillarity that takes place in addition to the occurrence of carbonation shrinkage, thus reducing the permeability of the concrete and therefore the possibility of diffusion of gases in concrete. This nature of the phenomenon was mentioned for the first time by Bakker in 1988, [19] and later by i.a. Nilsson (1996) [20], Fagerlund (1997) [21]. Such approach to the carbonation phenomenon was further developed in the DBME (WUT) under Czarnecki guidance - the obtained findings were widely published (e.g. [1], [2-5], [22-24]) concluding that concrete carbonation in urban-industrial conditions can be described with a hyperbolic function of carbonation depth in time (reciprocal square root of time) with an asymptote parallel to time axis. The asymptote value is considered as limit of carbonation depth. Traditional and hyperbolic carbonation models are shown on Fig. 2.

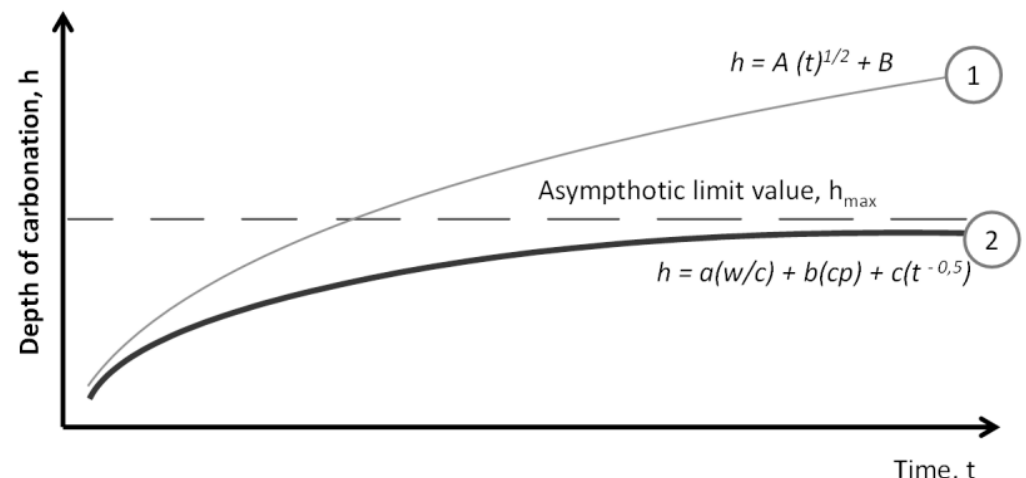

Fig. 2. "Traditional" power (1) and hyperbolic (2) models of carbonation phenomena.

The hyperbolic carbonation model is expressed in the form:

$$
h=a(w / c)+b\left(t_{e c}\right)+c\left(t^{-0.5}\right)
$$

where: $\mathrm{h}$ - depth of carbonation in $\mathrm{mm}$, w/c - water-cement ratio, $\mathrm{t}_{\mathrm{ec}}$ - early curing time in days, $\mathrm{t}$ - time of exposition in years, $\mathrm{a}, \mathrm{b}, \mathrm{c}$ - coefficients describing relevance of influence of w/c ratio, early curing and exposition time on depth of carbonation. It was stated that parameters a, b, c mainly depend on binder properties, presence of mineral additives and especially on $\mathrm{CO}_{2}$ concentration. Similar models were elaborated for different types of concrete with use of Portland cement and cement with slag and fly ash. SEM analysis showed different density of concrete structure in carbonated and non-carbonated zones. It was stated that all results are in accordance with following hyperbolic model:

$$
h=f\left(t^{-0.5}\right)
$$

regardless of binder composition, though various function coefficients were obtained for various cements. Determination of carbonation hyperbolic model enabled to specify the maximum carbonation depth and compare it with the thickness of concrete cover of 
reinforcement in the analyzed element. This enabled to indicate the possible risk of corrosion due to carbonation and to estimate the moment (time) when the carbonation front would reach the reinforcement which can be considered as the time of corrosion initiation.

\section{Hyperbolic carbonation model used in cover thickness design}

Determination of concrete cover thickness due to durability of construction located in conditions of the carbonation threat includes determination of the XC exposure class (acc. to EN 206) and selection of minimal cover thickness (acc. to EC2). Selecting minimal from the Eurocode, apart from exposure class $(\mathrm{XC} 1 \div \mathrm{XC} 4)$, one take into account only structural class $(\mathrm{S} 1 \div \mathrm{S} 6)$ and type of the reinforcement steel (mild steel, prestressed steel). Using the carbonation model obtained in the way of research for a particular type of concrete designed for use in structure, enables to design the thickness of the concrete cover for the individual case on the basis of the actual protective abilities of particular concrete. When designing one should take into account that if the process of carbonation is finite, the adopted thickness of the reinforcement concrete cover is greater than the maximal possible depth of carbonation (in the hyperbolic model the value of asymptote $h_{\max }$ ) which assures that the initiation of reinforcement corrosion would not arise in the structure. To simplify application of the hyperbolic model into designing practice, authors developed the algorithm [25] describing this experimental-computational step by step. An example of calculation of minimum concrete cover in reinforced element done according to that algorithm is given below.

\section{Example of calculation of the cover thickness for reinforced concrete element}

The calculation of concrete cover thickness was done for the reinforced concrete column of service life designed for at least 50 years in the following exposure environmental atmospheric conditions: relative humidity, $\mathrm{RH}$ up to $90 \%$, ambient temperature of $+(3 \div 40)^{\circ} \mathrm{C}$, natural $\mathrm{CO}_{2}$ concentration of c.a. $400 \mathrm{ppm}$. According to EN 2006, these conditions are adequate to carbonation exposure class $\mathrm{XC4}$. The control conditions of production and concrete works on site for the structure were set up as normal conditions. The material composition of concrete mix used to produce the analyzed element expressed per $1 \mathrm{~m}^{3}$ was as following: Portland siliceous fly ash cement of class 32,5 and high early strength: CEM II/A-V 32,5 R - $365 \mathrm{~kg}$, natural aggregate of fraction 0/16 mm (including river sand) $-1927 \mathrm{~kg}$, water $-155 \mathrm{dm}^{3}$, superplasticizer admixture $-1,3 \%$ of cement mass (i.e. $4,75 \mathrm{~kg}$ )._Above gived the water-cement ratio of 0,42 and according to Bolomey equation enabled to obtain concrete of compressive strength class $\mathbf{C 2 5 / 3 0}$. Laboratory tests performed on concrete specimens (cubes of size $15 \mathrm{~cm}$ ) cured under suitable moisture conditions for 28 days showed average concrete compressive strength of 39,1 MPa and the minimal compressive strength of $35,3 \mathrm{MPa}$ which according to EN 206 confirmed conformity with class $\mathbf{C 2 5 / 3 0}$. The applied self-terminated carbonation model was elaborated on the basis of results of concrete carbonation tests performed in the laboratory accelerated conditions ( $1 \%$ concentration of $\mathrm{CO}_{2}$, testing period : 90 days). The final value of minimal concrete cover thickness (after including safety margins and corrections beacuese of technological aspects) was calculated and was $\mathbf{2 0} \mathbf{~ m m}$, which is $30 \%$ less than the value obtained on the basis of Eurocodes EC0 and EC2 (Table 3). 
Table 3. Designing of cover thickness according to Eurocodes and with use of hyperbolic carbonation model on the example of for reinforced concrete column.

\begin{tabular}{|c|c|c|}
\hline $\begin{array}{l}\text { Designing of cover } \\
\text { thickness - steps }\end{array}$ & according to Eurocodes & $\begin{array}{c}\text { calculation with use of } \\
\text { hyperbolic carbonation model }\end{array}$ \\
\hline $\begin{array}{l}\text { Determination of the } \\
\text { expected service life of } \\
\text { structure/element \& } \\
\text { adequate structural class }\end{array}$ & $\begin{array}{c}\text { The service life of structure is } \\
\text { designed for at least } 50 \text { years, } \\
\text { which (Fig. 1) indicates the } \\
\text { structural class S4 }\end{array}$ & $\mathrm{X}$ \\
\hline $\begin{array}{l}\text { Determination of concrete } \\
\text { material composition for } \\
\text { the particular class }\end{array}$ & 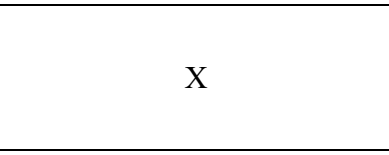 & $\begin{array}{l}\text { Concrete composition per } 1 \mathrm{~m}^{3} \text { : } \\
\text { cement }-365 \mathrm{~kg} \text {, aggregate - } \\
1927 \mathrm{~kg} \text {, water }-155 \mathrm{dm}^{3} \text {, super- } \\
\text { plasticizer }-1.3 \% \text { of } \mathrm{cm} \text {. }\end{array}$ \\
\hline $\begin{array}{l}\text { Analysis of exploitation } \\
\text { environment characteristics } \\
\& \text { potential structural class } \\
\text { correction (Fig. 1) }\end{array}$ & $\begin{array}{l}\text { Element in shape of column } \\
\text { (not slab); normal control } \\
\text { condition (no special quality } \\
\text { control); exposure class XC4, } \\
\text { concrete compressive class } \\
\text { C25/30 (lower than C40/50) - } \\
\text { no correction of struct. class }\end{array}$ & $\mathrm{X}$ \\
\hline $\begin{array}{l}\text { Preparation of specimens, } \\
\text { determining concrete } \\
\text { compressive class, carbona- } \\
\text { tion tests -carbonation } \\
\text { depth measurments done } \\
\text { after particular times of } \\
\text { exposure to } \mathrm{CO}_{2} \text { are data } \\
\text { for calculating the } \\
\text { carbonation model } \\
\end{array}$ & 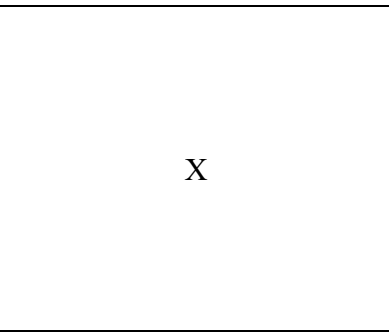 & $\begin{array}{c}\text { Average compressive strength of } \\
\text { concrete }\left(\mathrm{f}_{\mathrm{cm}}\right) \text { was } 39.1 \mathrm{MPa} \text { and } \\
\text { the lowest, minimal registered } \\
\text { value }\left(\mathrm{f}_{\mathrm{c}, \mathrm{min}}\right) \text { was } 35.3 \mathrm{MPa} \text { thus } \\
\text { class } \mathrm{C} 25 / 30 \text {. Concrete } \\
\text { specimens were exposed to } \mathrm{CO}_{2} \\
\text { of concentration } 1 \% \text { (RH } 60 \% \text {, T } \\
=20^{\circ} \mathrm{C} \text { ) for } 90 \text { days (accelerated } \\
\text { conditions) }\end{array}$ \\
\hline $\begin{array}{l}\text { Calculation of model - } \\
\text { relation «time of exposure } \\
\text { to } \mathrm{CO}_{2} \text { - concrete } \\
\text { carbonation depth» (Eq. 4.) } \\
\text { and its asymptote - limit of } \\
\text { carbonation depth* } \\
\end{array}$ & $\mathrm{X}$ & $\begin{array}{l}\text { Carbonation hyperbolic model } \\
\text { was calculated in the form: } \\
\mathrm{h}=13.6-33.8\left(\mathrm{t}^{-0.5}\right) \text {. The } \\
\text { asymptote of the function and at } \\
\text { the same time the maximal depth } \\
\text { of carbonation } \mathrm{h}_{\max } \text { is } 13.6 \mathrm{~mm} *\end{array}$ \\
\hline $\begin{array}{c}\text { Determination of } \\
\text { reinforcement type and } \\
\text { minimal concrete cover } \\
\text { thickness }\left(\mathrm{c}_{\text {min,dur }} \text { ) required }\right. \\
\text { in case of element located } \\
\text { in particular environment } \\
\text { described by exposure class } \\
\end{array}$ & $\begin{array}{l}\text { According to requirements } \\
\text { (Table } 2 \text { ) the minimal } \\
\text { concrete cover thickness of } \\
\text { reinforced (not prestressed) } \\
\text { element of structural class S4 } \\
\text { exposed to exposure class } \\
\text { XC4 } c_{\min , d u r}=30 \mathrm{~mm} .\end{array}$ & $\mathrm{X}$ \\
\hline $\begin{array}{l}\text { Determination of minimal } \\
\text { concrete cover thickness } \\
\left(\mathrm{c}_{\min , \mathrm{dur}}\right) \text { - the value must } \\
\text { be higher than possible } \\
\text { concrete carbonation depth } \\
\left(\mathrm{h}_{\max }\right) \text { from the model and } \\
\text { should be multiplied by } \\
\text { safety coefficient }(1.3) \text { and } \\
\text { adjusted to the accuracy of } \\
\text { stabilization of } \\
\text { reinforcement in formwork }\end{array}$ & 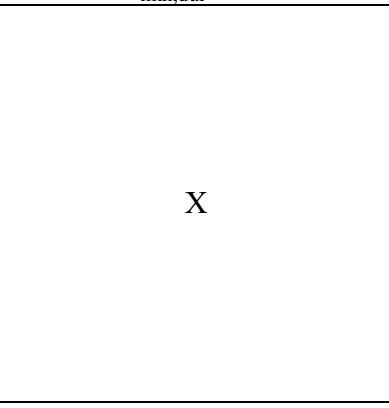 & $\begin{array}{l}\text { Maximal carbonation depth } \\
\left(\mathrm{h}_{\max }\right) \text { multiplied by safety } \\
\text { coefficient of } 1.3 \text { gives minimal } \\
\text { concrete cover thickness, } \mathrm{c}_{\text {min,dur }} \\
=17.7 \mathrm{~mm} \text {. Due to accuracy of } \\
\text { stabilization of reinforcement in } \\
\text { formwork, the minimal concrete } \\
\text { cover thickness in analyzed } \\
\text { reinforcement concrete element } \\
\text { is } 1.3 \cdot \mathrm{c}_{\mathrm{min}, \mathrm{dur}}=20 \mathrm{~mm} .\end{array}$ \\
\hline Final result & $30 \mathrm{~mm}$ & $20 \mathrm{~mm}$ \\
\hline
\end{tabular}

*) value $10 \div 15 \%$ higher than value obtained for the same concrete after many years of exposure to natural atmospheric conditions ( $400 \mathrm{ppm}$ of $\mathrm{CO}_{2}$ ) thus $\mathrm{h}_{\max }$ is a bit excessive (on a safe side) 


\section{Conclusions}

Presented example of designing the concrete cover thickness in reinforced element in two ways confirms that elaborating the precise and accurate mathematical models of concrete carbonation describing the increase of the carbonation depth in concrete in time and application of such models for designing the reinforced structures in terms of ensuring the required durability is useful and reasonable. The example clearly showed that estimating of minimal concrete cover thickness in terms of carbonation threat on the basis of the Eurocodes EC0 and EC2 and European standard 206 is an overestimation and significantly increases the cost of whole structure. However one should be sure about the correctness of the elaborated model. Authors hope that presented analysis of the "traditional" carbonation models in the context of their deficiencies in describing the phenomenon of carbonation, which actually is terminated phenomenon, will encourage others to use more correct models described by hyperbolic functions, as in case of given example.

\section{References}

1. P. Woyciechowski, Scientific works. Buildings (OWPW, Warszawa, 2013)

2. L. Czarnecki, P. Woyciechowski, ACI Mater. J. 109, 3 (2012)

3. L. Czarnecki, P. Woyciechowski, B. Pol. Acad. Sci-Tech. 61, 1 (2013)

4. L. Czarnecki, P. Woyciechowski, B. Pol. Acad. Sci-Tech. 63, 1 (2015)

5. L. Czarnecki, P. Woyciechowski, Proc. 4th Int. Conf. on Concrete Repair, Rehabilitation and Retrofitting (ICCRRR-4) (CRC Press, Leipzig-Capetown, 2016)

6. B. Bary, A. Sellier, Cem. Concrete Res. 34,12 (2004)

7. O. Burkan Isgor, A. Ghani Razaqpur, Cem. Concrete Comp. 26 (2004)

8. K.M.A. Hossain, M. Lachemi, Proc. Third Int. Conf. on Constr. Mater.: Performance, Innovations and Structural Implications, (Vancouver, 2005)

9. T. Ishida, K. Maekawa, M. Soltani, , J. Adv. Concrete Technol. 2, 2 (2004)

10. K. Maekawa, T. Ishida, Mater. Struct. 35 (2002)

11. Y.H. Loo, M.S. Chin, C.T Tam, K.C.G. Ong, Mag. Concrete Res. 46 (1994)

12. Y. Masuda, H. Tanano, Concrete Res. Technol. 2, 1 (1991)

13. M.T. Liang, W. J. Qu, C.-H. Liang, J. Mar. Sci. Technol. 10, 2 (2002)

14. I. Monteiro, F.A. Branco, J. de Brito, R. Neves, Constr. Build. Mater. 29 (2012)

15. A. Steffens, D. Dinkler, A. Ahrens, Cem. Concrete Res. 32 (2002)

16. V.G. Papadakis, C.G Vayenas, M.N. Fardis, ACI Mater. J. 88 (1991)

17. A. Muntean, Meccanica 44, 1 (2009)

18. CEB Bulletin 238, New Approach to Durability Design. An example for carbonation induced corrosion (Comitée Euro-International du Béton CEB 238, 1997)

19. R.F.M. Bakker, Corrosion of steel in concrete: Report of the Technical Committee $60-$ CSC RILEM (Chapman and Hall, London, 1988)

20. L-O. Nilsson, Constr. Build. Mater. 10, 5 (1997)

21. G. Fagerlund, Trwatość konstrukcji betonowych (Arkady, Warszawa, 1997)

22. L. Czarnecki, R. Więcławski, Proc. MATBUD 2003 (PK, Kraków, 2003)

23. L. Czarnecki, R. Więcławski, Int. Congr. on Concrete Durability (Trondheim, 2012)

24. L. Czarnecki, J.J. Sokołowska, B. Pol. Acad. Sci-Tech. 63, 1 (2015)

25. P. Woyciechowski, J.J. Sokołowska, Prof. Of Advances in Civil, Environmental and Materials Research (ACEM16) (Techno-Press, Jeju, 2016) 